\title{
RISK ANALYSIS OF LANDSLIDE IMPACTS ON SETTLEMENTS IN KARANGANYAR, CENTRAL JAVA, INDONESIA
}

\author{
Kuswaji Dwi Priyono*, Jumadi, Aditya Saputra and Vidya Nahdhiyatul Fikriyah
}

Faculty of Geography, Universitas Muhammadiyah Surakarta, Surakarta 57162, Indonesia

${ }^{*}$ Corresponding Author, Received: 06 March 2020, Revised: 02 April 2020, Accepted: 27 April 2020

\begin{abstract}
Indonesia is prone to landslides resulting from high variability in topographic conditions and rainfall characteristics. These events are likely to increase in frequency because of the spread of land degradation in the region. At least 50 landslide occurs every year between 2003-2005 in West Sumatra, North Sumatra, South Sulawesi, Papua, and Java Island including the research area, Karanganyar district, Central Java. This study aims to analyze the risk of landslides on settlements in Karanganyar district, Central Java, Indonesia. The integrated method between the statistical methods, field observation, and spatial analysis using Geographic Information Systems (GIS). The bivariate statistical approach was applied to determine the weight of each variable, based on existing landslide events. A black box model based on the landslide density analysis was prepared by connecting the primary data for landslide events and the parameters applied (topography, geology, soil, land use and the rainfall intensity). The level of risk was then analyzed by applying the function risk = hazard $\mathrm{x}$ vulnerability to the GIS platform. The results show that landslide tend to occurs in the area with physical characteristics as follow: slope between 8-150; consists of Wonosari Formation (sediment reeflimestone); reddish brown latosol; utilized as dry land farming; and has high rainfall intensity (4,000-5,000 $\mathrm{mm}$ / year). These model can be used to generate landslide-damage and risk-distribution maps of settlements which could be used for mitigation purposes.
\end{abstract}

Keywords: Landslides, GIS, Remote sensing, High-resolution imagery, Risk analysis, Vulnerability analysis

\section{INTRODUCTION}

Indonesia is an archipelago which is also known for its location in the zone of active tectonic plates. It is also a country with tropical climate that has characteristic of high rainfall intensity and humidity. In consequence, this geographic and climatic condition cause Indonesia to be a vulnerable region of floods, volcanic eruption, earthquakes, and landslide. Landslide is a serious hazard that can bring damage to economic assets (building and productive land) and loss of life. It is characterized by the local occurrence (hilly and mountainous region), fast movement, and triggered by high intensity and long term of rainfall that usually happen in the rainy season.

Indonesia in particular is prone to landslides because of its highly variable topographic conditions and rainfall characteristics. These events are likely to increase annually as the impact of land degradation and land-use changes spreads [1]. According to National Disaster Management Agency of Indonesia [2], almost 40.9 million people in Indonesia are highly exposed to the danger of landslide, especially people who live in the upland and hilly area. It is known that province of West Java, Central Java, and Banten are among the most prone regions to landslide. For the period of 20032005, at least 103 landslides occurred in Java Island, West Sumatra, North Sumatra, South Sulawesi and
Papua. These events caused large numbers of casualties (411 death tolls and 149 injured), badly damage to 4,608 of houses and 751 ha of farmland destruction and 920 of damaged roads [3-4]. As part of landslide mitigation efforts, research is, therefore, urgently required to identify the associated risks.

Situated on the western flank of the volcano of Lawu, Karanganyar district is dominated by steep slopes and experiences high intensity of rainfall. These conditions lead to extensive erosion, weathering and mass wasting including landslides, especially in the eastern part of Karanganyar district. Additionally, in some parts of this district there are several critical landslide areas resulting from high levels of geomorphic activity, while areas such as Kembang, Kopen, Girimulyo and Slogoretno are experiencing land degradation. These conditions are exacerbated by human activities that ignore land conservation and regulation as part of landslide disaster-mitigation efforts. A significant amount of unsuitable land use, such as fields for farming and rice cultivation and logging activities, is frequently found on steep slope areas. Moreover, the development of tourism activities in Karanganyar (for example in Tawangmangu, Ngargoyoso, and Mount Lawu) has increased the economic activities and this condition has led to the land use changes [5].

Given the aforementioned issues, efforts to identify and characterize landslide hazards in the 
study area are vitally needed. This study can be used to support landslide-risk assessment and to provide guidelines for designing suitable land-use plans. Furthermore, considering the location of where people live, the quantification of potential risk in the settlement/residential land of study area is especially important.

Landslide hazard and risk mapping is challenging. Currently, there are various methods and types of datasets that can be used to characterize landslide hazards [6-10]. Among others, hazard and risk identification using statistical test is the most widely used approach, for instance, test using simple regression, logistic regression, bivariate, as well as bivariate analysis [11-13]. The use of statistical test (logistic regression, for example), has advantage to be combined with bivariate statistical analysis (BFA) to simplify the relationship model between landslide events and related independent variables [13].

Theoretically, the occurrence of landslides is strongly controlled by the prevailing topographic conditions; consequently, relief characteristics, such as slope and aspect are the most important data in every type of landslide inventory technique [10]. Several types of data can be used to provide information about topographic characteristics, such as digital elevation models (DEM) [14] and digital terrain models (DTM) generated from LiDAR data for better elevation accuracy [7]. Several studies, such as Ayalew and Yamagishi [8], Leshchinsky, Olsen, and Tanyu [7] and Pike [9] have explained that using topographic and relief data are effective for characterizing the likelihood of landslide occurrence. Other physical data also have been used by prior studies, for instance geology and soil data [10], and rainfall data [15].

A comprehensive landslide inventory is needed to quantify the landslide hazard and risk [10]. Considering all technique and data that have been used by prior studies, landslide mapping and analysis can be improved further by integrating data from multiple sources (remote sensing and field data) [16]. Therefore, this study combines statistical analysis [17], field observation [18] and spatial analysis techniques [19] to identify landslide hazard and to analyze the landslide risk to residential areas.

\section{MATERIALS AND METHODS}

\subsection{General Framework}

The general function for risk was used to determine landslide-risk level in the study area $[20,21]$. Risk is defined as hazard multiplied by vulnerability and this study was therefore divided into three major parts: landslide hazard, vulnerability and risk analysis (Figure 1). In general, hazard mapping was conducted through bivariate analysis using land physical characteristics (land use, slope, geology, soil, and rain intensity) as the independent variables. This data were linked to the landslide occurrences obtained from field survey. A total of 997 landslide locations were identified in mostly the eastern part of Karanganyar district. In bivariate analysis, the weight of each variables was calculated based on the its relationship to landslide occurrence. The weight of each variable was obtained from landslide density analysis using the Eq. (1) below [11].

$W i=\ln \left(\frac{\text { Densclass }}{\text { Densmap }}\right)$

Where $\mathrm{Wi}$ is the weight given to a certain parameter used, dens class is the landslide density within parameters class, and densmap is the landslide density within the entire map. Then hazard map was then produced through the overlay of all weighted variable. On the other hand, Quickbird imagery was visually interpreted to delineate buildings and to discriminate between urban and rural area, since rural area is considered more vulnerable due to the building construction and its location. Building density was also calculated with the help of GIS. The results of this step is the settlement vulnerability map. Finally, both maps of hazard and settlement vulnerability maps were combined to produce the settlement risk map.

Detail explanation of each part will be presented in this section using only limited data; the full spatial datasets of the landslide-risk assessment can be downloaded from doi: 10.17605/OSF.IO/G2UG6.

\subsection{Study Area}

The study site is located in Karanganyar district (Figure 2) and has an average altitude of 1,200 m above sea level (ASL). Topographical conditions indicate that the area is very susceptible to landslide. In 2007, two major landslides occurred in Tawangmangu sub-district, resulting in 34 fatalities and the collapse of 33 houses (Setiawan and Hizbaron, 2014). The area is located at coordinates 11043 ' 38 "- 111 11' 24" east and 7 6' 17"- 746 '07" south and is geographically located on the slopes of the western flank of Mount Lawu. Karanganyar district covers 773,378.64 ha, with an average altitude of $511 \mathrm{~m}$ ASL, with variation between 105 and 2,000 m ASL. Climate type in Karanganyar is classed as Type B (wet) according to Schmidt-Ferguson climate classification, and this is one of the influencing factors in landslide occurrence in the area. Daily rainfall data for 10 years gives average annual rainfall of 3,016 mm, with the average wettest month being January 
(530.7 $\mathrm{mm}$ ) and the average driest month being July (32.9 mm). The mean number of wet months ( $>100$ $\mathrm{mm}$ ) is eight (October to May) and the mean number of dry months $(<60 \mathrm{~mm}$ ) is four (June to September). Highest intensity rainfall in January and February has triggered landslide disasters in some areas in Karanganyar. The high intensity of rainfall with percolation of rainwater accelerates the saturation of the bottom layer, which then serves as a sliding plane, and triggering further landslide events.

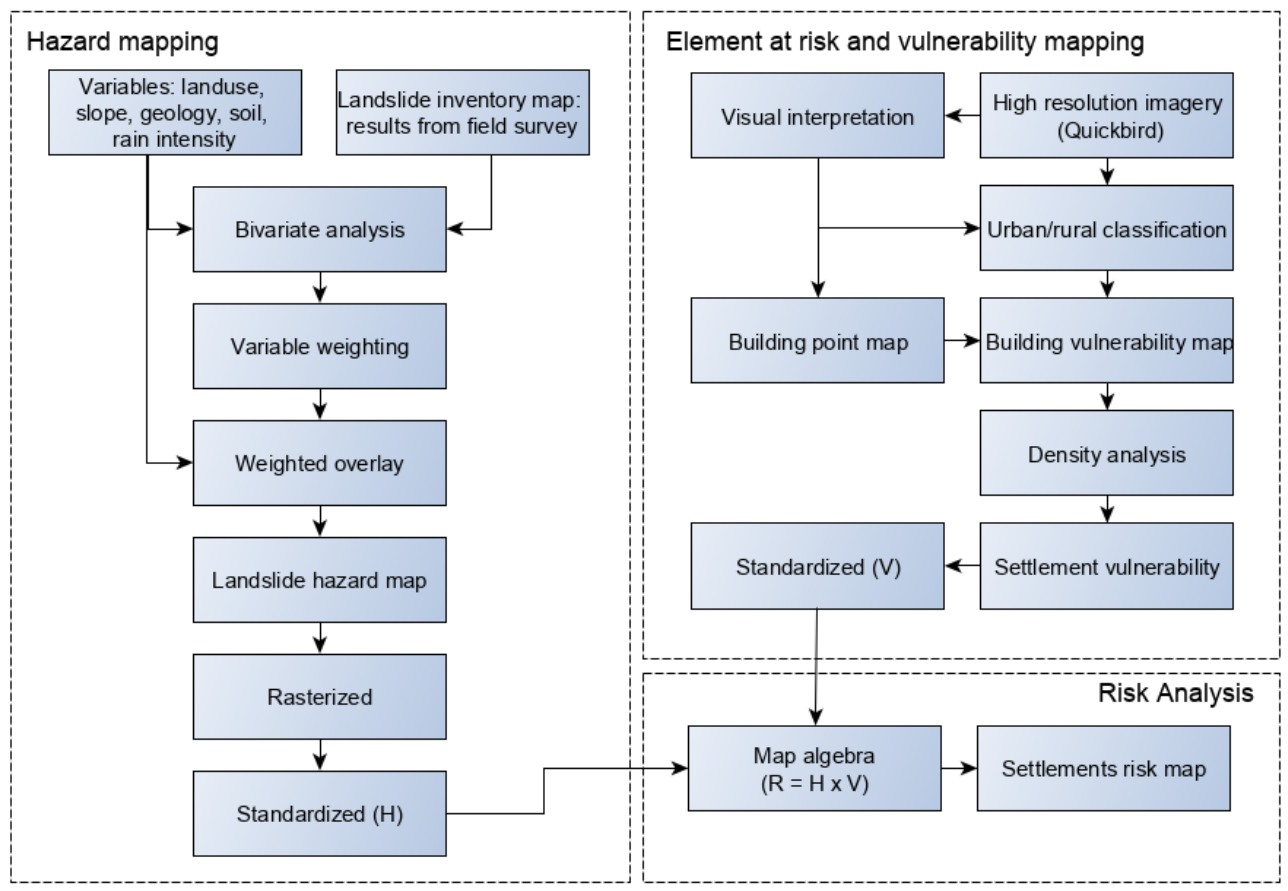

Fig.1 Research framework.

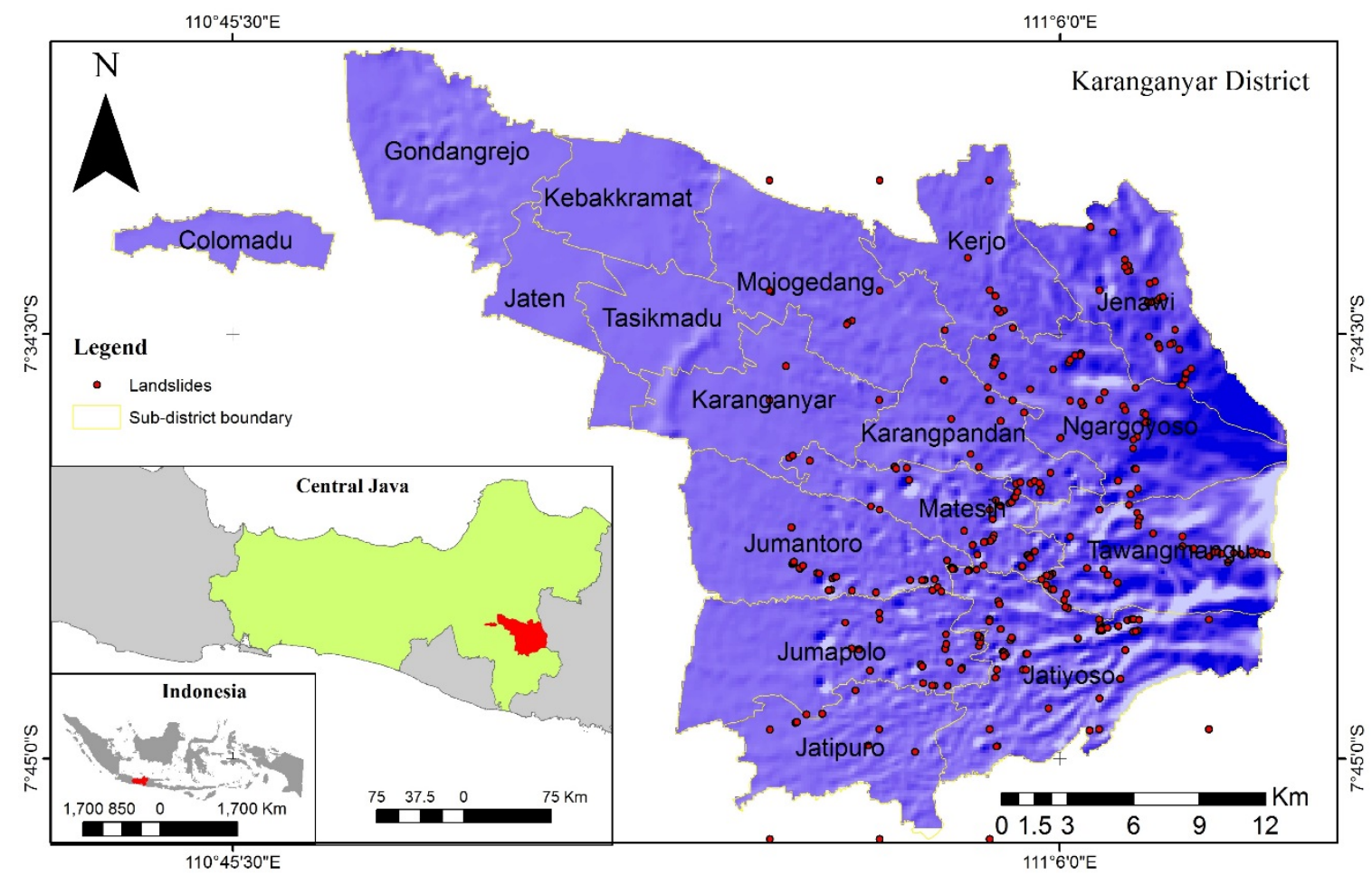

Fig.2 Study area in Karanganyar district.

The geomorphological characteristics of this area can be summarized as follows (Priyono et al.,
2015): (1) major soil type: litosol, Mediterranean, andosol, grumusol, and regosol; (2) topography: 
$38.35 \%$ is flat while $65.65 \%$ is mountainous; and (3) lithology: this area is formed of part of the lahars of Lawu, lava, and the volcanic rocks of Sidoramping Lawu. The lahars of Lawu consist of andesite components, basalt and some pumice, varied in size and mixed with volcanic sand. Regional conditions feature rocks of the Quaternary period composed of volcanic rocks such as breccia and tuffs which are estimated to be prone to movement, especially where truncated by faults and having experience of weathering.

\subsection{Landslide Hazard Mapping}

The integration of bivariate statistical methods, GIS and validation in the field was used to develop the landslide hazard map. The bivariate statistical analysis between the predisposing factors for landslide and the landslide-data inventory produced the weight of each variable. This weighting was then used in weighted overlay steps to determine landslide hazard.

In general, this study is divided into four main stages: preparation, data acquisition, landslide vulnerability assessment and validation in the field. The preparation stage covers the determination of the research objectives, scale analysis, methodology selection and the determination of the data required. In this phase, a literature study on landslide hazard and vulnerability assessment were conducted. The second phase was the data acquisition stage and consisted of spatial data acquisition through fieldwork, image interpretation and processes involving GIS.

This second stage aims to prepare raw data for characteristics such as geology, soil, slope, land use and erosion. The third stage is the landslide hazard assessment using the bivariate statistical approach. In this study, bivariate analysis was conducted by dividing the density of landslide per class by the density of landslide in the entire area. Natural logarithm was used to provide a negative weighting when the landslide density is lower than normal, and positive weighting when higher than usual, and by combining two or more weight-value maps, landslide hazard maps can be created. The landslide hazard map was obtained from the assessment by simply adding highly separated values (See [5], for more details). At this stage all of the variables were statistically analyzed and tested against the landslide-occurrence data. The resulting weight of each variable was then used in the overlay process using GIS platforms to produce the landslide hazard map. This approach is often referred as Black Box model, where the statistical test was used to determine the weight of each variables, and thus the most influential factors can be identified [5]. Finally, the hazard map was validated in the field.

\subsection{Element at Risk (Settlements) and Vulnerability Mapping}

The vulnerability of the element at risk (buildings) was classified from its characteristics. Then, the vulnerability of settlements was generated from individual building vulnerability. The assumption was that there are differences between the characteristics of rural buildings and urban buildings and used this assumption to characterize vulnerability, as based on research by Hizbaron et al. [22] which identified different vulnerabilities among various type of building. The analysis of building vulnerability was conducted according to the type of building structure whether it is wood, brick, or concrete. Buildings made of wood which are commonly found in rural areas are more vulnerable to damage than buildings using concrete structure. In this research, urban buildings are identified as low damage after impact by landslide, whereas rural buildings are identified as high damage. A high resolution imagery (Quickbird, dated 2004/2005) was used to assign rural and urban classifications, following the approach from a study [23]. This information is needed as indicator for the exposure to landslide (the building density and location with respect to landslide occurrence). Urban areas are characterized as having high density of buildings and/or proximity to a major road and this information was extracted from the imagery by visual interpretation. Rural/urban area classification and building location were overlaid afterwards to provide the map of building vulnerability. The settlement vulnerability map was created by analyzing the density of the building vulnerability map with vulnerability value used as weight (kernel density analysis in GIS was employed).

\subsection{Risk Analysis}

The settlement risk map was generated by calculating raster data for both hazard and vulnerability using the formula risk = hazard $\mathrm{x}$ vulnerability. Both the hazard map and the vulnerability map were standardized using minmax rescaling transformation before the processing. From this result, the distribution of risk in the study area can be analyzed.

\section{RESULS}

Studies have emphasized the importance of landslide hazard and risk mapping for disaster mitigation. While some studies applied either statistical model, spatial analysis, or in situ measurement only, this study attempts to improve the mapping technique by combining the statistical test- bivariate analysis with spatial analysis in GIS 
and direct checking of landslide events on the ground. As population and buildings are element at risk of landslide, a particular attention to the settlement area for this hazard and risk mapping was given. Our results and discussion parts are divided into hazard, vulnerability, and risk analysis in the following sub-sections.

\subsection{Landslide Data Inventory}

The landslide data inventory was the important steps in this study. Without proper landslide data inventory the landslide density analysis cannot be obtained. As a result, the weight of each parameter is unknown. Based on the field observation, this study succeeds to collect at least 997 landslide occurrences in study area. The field observation was useful to obtain the landslide occurrence location (point format) and the area of landslide (polygonal format). The results showed that most of landslide occurrence were distributed in the middle to east part of study area. The landslide data inventory can be seen in Figure 2.

\subsection{Landslide Hazard Assessment (Density Analysis)}

Hazard assessment was done by calculating landslide density (Equation 1) in all parameters, i.e., slope, geology, soil, landuse, and rainfall intensity. The results show that around $42.18 \%$ of total landslide occurred on sloping slope (8-150) or around 213.05 ha from the total active slide of 505.07 ha. Only around $10.83 \%$ of active landslide were located on steep slope (15-300). Thus, based on the equation 1 the highest weight of slope is sloping (8-150), step (15-300), and gentle slope $(>300)$ which has the value of weight of 0.813 , 0.232, and 0.200 , respectively (see https://osf.io/ad3j2/). This results are in line with the other landslide research in Yogyakarta which was conducted by Samodra et al. [24] and Saputra et al. [25]. Both research found that the most of landslide and coseismic landslide were located not on the steep slope but sloping slope.

In the parameter of lithology, most of landslide were located on the Lahar Lawu (Extrusive volcanic rock). The active landslide that located in this units is around 205.96 ha from the total active slide of 505.96 ha or $40.70 \%$ of the total active slide. However, based on the landslide density analysis, the highest weight on this parameter is located on the Wonosari rock formation which consists of reef sediment and limestone (see https://osf.io/7fkq2/).

In the soil and landuse parameters. The highest weight is located in Reddish brown Latosol and dry farming land, respectively. The reddish brown Latosol has the weight of 0.260 while the dry farming land is 0.426 . The reddish brown Latosol has highest weight in the soil parameters because it consists of intermediate volcanic tuff which is easier to eroded than the other type of soil (see https://osf.io/6k2v4/). Similar with this, dry land farming usually located on the unconsolidated soil which has higher clay contains. Thus, when the rainfall come this area become not stable and prone to landslide occurrences (see https://osf.io/5gbam/).

The relationship between landslide and rainfall parameter in this study also follow the general concept. The higher the rainfall intensity is the higher the landslide occurrences. Most of the landslide or around 184.14 ha were located in the area that has highest rainfall intensity (3,000-4,000 $\mathrm{mm} /$ year) (see https://osf.io/8cxr5/). Figure 3 is presented to summarize all the input map in this study.

\subsection{Landslide Characteristics}

The results shows that landslides in Karanganyar tended to occur in a number of situations: (1) on moderate slopes, in slope class 8$15 \%$ toward the peak of Mount Lawu on the east side of Karanganyar. It is estimated that the concentration of rainwater percolating in this slope is relatively large, so that the sliding layer is rapidly saturated. The same phenomenon was found in Banjarnegara, Central Java [26] and Kulon Progo in Special Region of Yogyakarta [5]; (2) on old rock i.e. Quarternary lithology. These are either breccia or tuff from Lawu volcanism which has undergone intense weathering. Wonosari Formation is robust while the rocks overlaying it, including breccia and andesite, are parallel and easily weathered and therefore prone to landslide. In Jobolarangan, breccia and lava rocks have Sidoramping fault structure which make them landslide-prone; (3) on thick soil due to massive weathering; such soil can be reddish-brown latosol, yellowish-brown andosol complex and litosol, and Mediterranean brown. The third kind of rocky soil comes from parent rock composed of Luwa lava, Jobolarangan breccia rocks, and Sidoramping lava rock. Soil that originates from volcanic activity is also known to be fertile. As a result, the area with this kind of soil is widely used for agricultural land (rainfed rice field and garden). Many of this agricultural land is located on the slopes on mountain which lower the slope stability and can trigger landslides. Based on the analysis of land use with the extent and frequency of existing landslide, the obtained weighting factor that triggers landslide incidents in Karanganyar is largest on landforms comprising fields and combined fields and gardens. Use of upland/moor and gardens dominant in hills/mountains with slopes of over $15 \%$ are also prone to landslide.

In the dry season, soil in land-use areas is 
generally dry and so the soil surface is cracked. At the beginning of the rainy season, high-intensity rainfall causes water to easily pass through these cracks into the impermeable rock zone below, causing catastrophic landslides. Exogenous processes that occur are mainly due to local climatic conditions, including input of rain and temperature fluctuations, flow of water and the effects of gravity, and these processes include, among others, weathering, erosion and landslide. The weathering process that typically occurs is in andesite, exposed in several locations in Karanganyar. Weathering results from onion-peel excoriation (spheroidal weathering) with the core of rock still appearing fresh. The existence of minor fractures with irregular direction in many andesite rocks results in easily weathered rocks and rock fragments easily separated from their cement binder, characteristics which trigger landslides.

\subsection{Vulnerability Map}

Building vulnerability derived from visual interpretation is provided in Figure 4a, and settlement vulnerability generated by density analysis of building vulnerability is provided in Figure 4b. Using a rural-/urban-areas approach can quickly provide a vulnerability map for buildings as presented in these figures. The result is quite generalized and will be less precise than an approach which interprets individual buildings $[27,28]$, but applying this latter method for such a wide area would be less effective. Based on Figure 4a and $4 \mathrm{~b}$, it is apparent that the high vulnerable settlements are concentrated in the southern and northern part of Karangnyar where it is the high density in rural area.
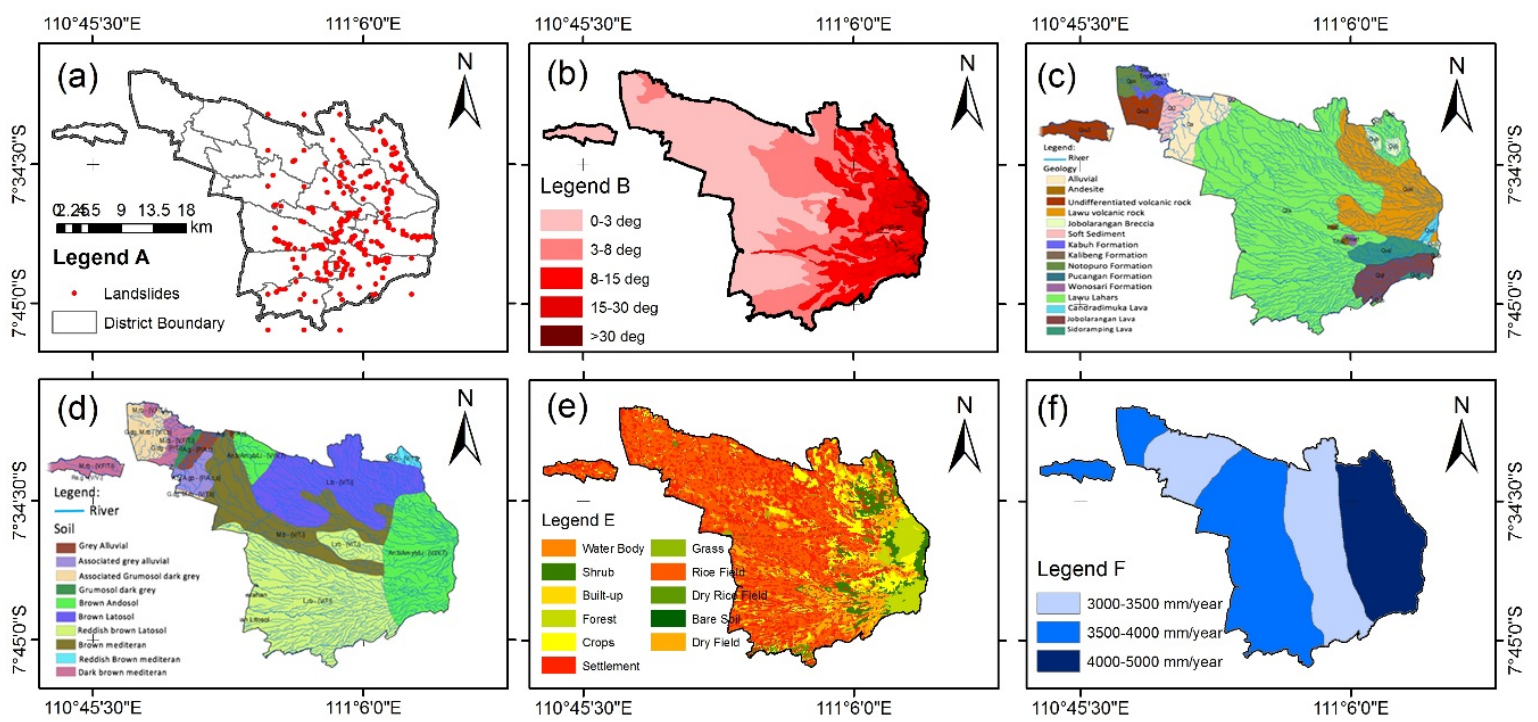

Fig. 3 Datasets. (a) Landslides occurrences, (b) slope, (c) geology, (d) soil, (e) landuse, and (f) rainfall intensity.
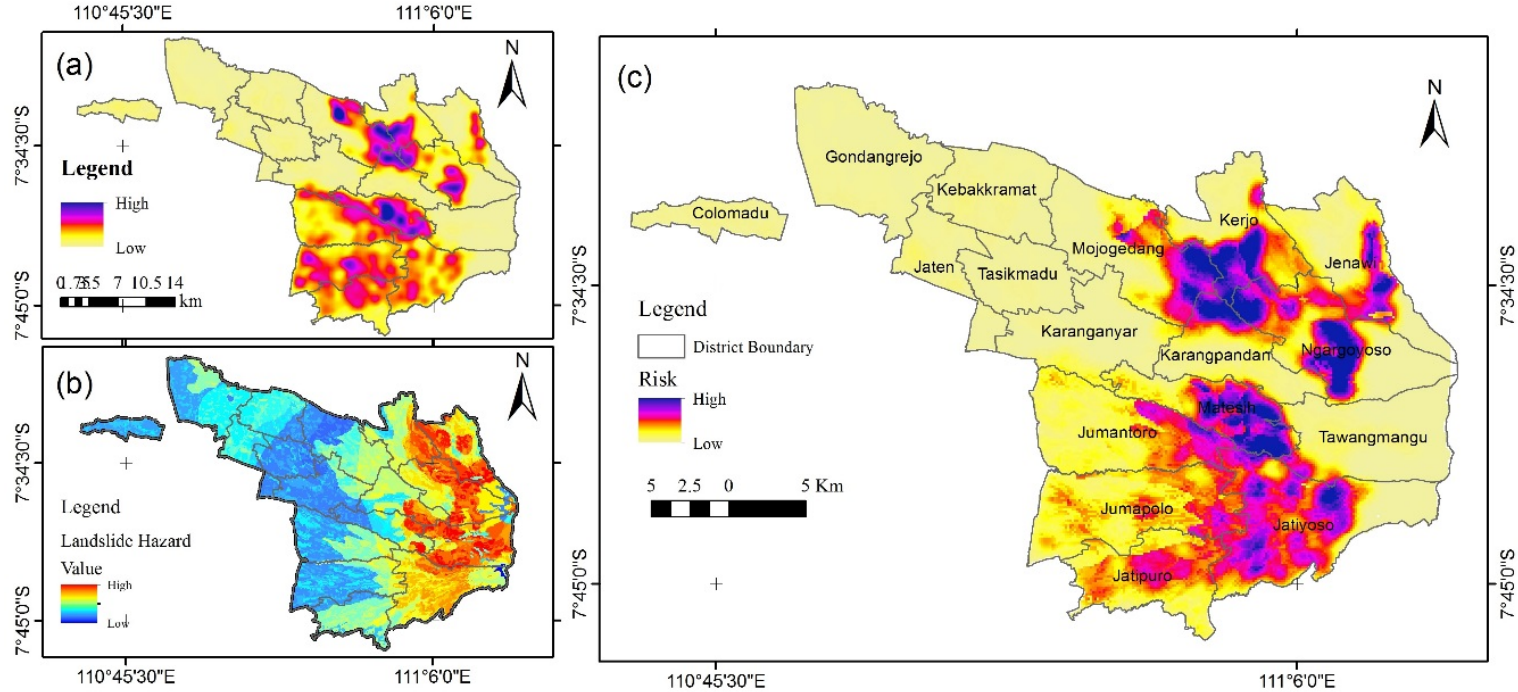

Fig. 4 The Results of Analysis. (a) building vulnerability, (b) landslide hazard, (c) the risk map of landslide impact to settlement. 


\subsection{Risk Map}

The results for settlement risk damage by landslide are provided in Figure 4c. As the map was generated from hazard and vulnerability, this map expresses the density of building along with vulnerability properties and the hazard map along with hazard-level properties. The hazard map expresses landslide susceptibility in relation to geographic characteristics as well as the density of landslide occurrences based on field surveys. The method used in this research is drawn from Guillard-Gonçalves, Zezere, Pereira, and Garcia [28].

The Figure 4c shows that high risk to settlements from landslide in Karanganyar is spread across Jatiyoso, Ngargoyoso, Matesih, Karangpandan, Kerjo, Jenawi and Mojogedang districts. Although some areas of Tawangmangu are in a highly susceptible area for landslide based on geographic characteristics, only a few parts of the area are at high risk because most of the settlements in this area have low vulnerability toward landslide impacts due to the improvement with structural mitigation.

Although the results of this study have limitations due to the generalization of vulnerability identification, this research can provide a better understanding of landslide risk to settlements that will be important for disaster-risk reduction and planning. This research improves on previous research in the same area that only focuses on hazard occurrences $[5,29,30]$ or community perceptions [31]. The earlier focus of research, i.e. hazard occurrences, is important in mapping the hazard based on the historical events, but still unable to map the risk since there is limited information about the exposures. While the latter, community perception, focus on the social aspects that, in future work, can be linked with the risk level of their location based on this research.

\section{CONLUSIONS}

Understanding the level of landslide risk in settlement area is essential for disaster mitigation. To achieve a more comprehensive approach of hazard and risk mapping, in this study we presented the landslide-risk analysis based on the integration of statistical analysis, field survey and spatial (GIS) analysis. From the statistical analysis validated with field survey, it can be concluded that landslide in the study area commonly occurs on: 1) moderate slopes; (2) old rocks; and (3) thick soil resulting from massive weathering. The method demonstrated in this paper can provide speedy risk analysis with relatively wider coverage. Moreover, the presented settlement risk damage can express the characteristics of both element-at-risk vulnerability and hazards, consistent with established risk theory. Despite the limitation in the results of this risk map, due to the generalization process during the vulnerability identification, our approach is more favourable to be applied in a wider region. In addition, the resulted maps provides risk information specifically in the settlement area which have not been accommodated yet by previous research. We suggest that a further study incorporating data of capacity for the risk analysis needs to be done to fully understanding the landslide risk in the study area.

\section{ACKNOWLEDGMENTS}

This research was funded by LPPM, Universitas Muhammadiyah Surakarta. We gratefully acknowledge the anonymous reviewers who give constructive feedbacks.

\section{REFERENCES}

[1] Kurniawan, A.; Krol, B.G.C.M. (Bart) Spatio Temporal Analysis of Land Use Change for Supporting Landslide Exposure Assessment. Indones. J. Geogr. 2014, 46, 104-124.

[2] Bhwana, P.G. BNPB: 40.9 Million People Live in Areas Prone to Landslide Available online:

https://en.tempo.co/read/1161193/bnpb-40-9million-people-live-in-areas-prone-tolandslide (accessed on Feb 10, 2020).

[3] BNPB, BNPB Available online: http://dibi.bnpb.go.id/DesInventar/dashboard. jsp?countrycode $=$ id\&continue $=$ y\&lang $=$ ID (accessed on Nov 26, 2014).

[4] Hadmoko, D.S.; Lavigne, F.; Sartohadi, J.; Gomez, C.; Daryono, D. Spatio-Temporal Distribution of Landslides in Java and the Triggering Factors. Forum Geogr. 2017, 31, 115-15.

[5] Priyono, K.D.; Saputra, A.; Jumadi Model Black Box untuk Identifikasi Tingkat Kerawanan Longsorlahan (Landslide Susceptibility) di Kabupaten Karanganyar, Jawa Tengah. 2015.

[6] Mukenga, W.; Havenith, H.-B.; Medjo Eko, R.; Dewitte, O. Spatial Analysis of the Landslide Risk in the Cameroon Volcanic Line (CVL). 2016.

[7] Leshchinsky, B.A.; Olsen, M.J.; Tanyu, B.F. Contour Connection Method for automated identification and classification of landslide deposits. Comput. Geosci. 2015, 74, 27-38.

[8] Ayalew, L.; Yamagishi, H. The application of GIS-based logistic regression for landslide susceptibility mapping in the Kakuda-Yahiko 
Mountains, Central Japan. Geomorphology 2005, 65, 15-31.

[9] Pike, R.J. The geometric signature: Quantifying landslide-terrain types from digital elevation models. Math. Geol. 1988, 20, 491-511.

[10] van Westen, C.J.; Castellanos, E.; Kuriakose, S.L. Spatial data for landslide susceptibility, hazard, and vulnerability assessment: An overview. Eng. Geol. 2008, 102, 112-131.

[11] Alkema, D.; Kerle, N.; Kingma, N.C. Multihazard risk assessment. 2011.

[12] Ahmed, B.; Dewan, A. Application of Bivariate and Bivariate Statistical Techniques in Landslide Susceptibility Modeling in Chittagong City Corporation , Bangladesh. 2017.

[13] Reichenbach, P.; Rossi, M.; Malamud, B.D.; Mihir, M.; Guzzetti, F. A review of statistically-based landslide susceptibility models. Earth-Sci. Rev. 2018, 180, 60-91.

[14] Glenn, N.F.; Streutker, D.R.; Chadwick, D.J.; Thackray, G.D.; Dorsch, S.J. Analysis of LiDAR-derived topographic information for characterizing and differentiating landslide morphology and activity. Geomorphology 2006, 73, 131-148.

[15] Liu, J.K.; Shih, P.T.Y. Topographic correction of Wind-Driven rainfall for landslide analysis in central Taiwan with validation from Aerial and satellite optical images. Remote Sens. 2013, 5, 2571-2589.

[16] Zhao, C.; Lu, Z. Remote sensing of landslidesA review. Remote Sens. 2018, 10, 8-13.

[17] Carrara, A.; Cardinali, M.; Detti, R.; Guzzetti, F.; Pasqui, V.; Reichenbach, P. GIS techniques and statistical models in evaluating landslide hazard. Earth Surf. Process. Landf. 1991, 16, 427-445.

[18] Brardinoni, F.; Slaymaker, O.; Hassan, M.A. Landslide inventory in a rugged forested watershed: a comparison between air-photo and field survey data. Geomorphology 2003, 54, 179-196.

[19] Perotto-Baldiviezo, H.L.; Thurow, T.L.; Smith, C.T.; Fisher, R.F.; Wu, X.B. GIS-based spatial analysis and modeling for landslide hazard assessment in steeplands, southern Honduras. Agric. Ecosyst. Environ. 2004, 103, 165-176.

[20] Sar, N.; Chatterjee, S.; Adhikari, M.D. Integrated remote sensing and GIS based spatial modelling through analytical hierarchy process (AHP) for water logging hazard, vulnerability and risk assessment in Keleghai river basin, India. Model. Earth Syst. Environ. 2015, 1, 1-21.

[21] UNISDR Living with risk: A global review of disaster reduction initiatives; United Nations International Strategy for disaster Reduction, Geneva, Switzerland, 2004;

[22] Hizbaron, D.R.; Dalimunthe, S.A.; Hadmoko, D.S.; Samodra, G.; Sartohadi, J. Tinjauan Kerentanan, Risiko dan Zonasi Rawan Bahaya Rockfall di Kulonprogo, Yogyakarta. Review of Vulnerability, Risk and Rockfall Danger Prone Zoning in Kulonprogo, Yogyakarta 2010.

[23] Thomas, N.; Hendrix, C.; Congalton, R.G. A comparison of urban mapping methods using high-resolution digital imagery. Photogramm. Eng. Remote Sens. 2003, 69, 963-972.

[24] Hadmoko, D.S.; Lavigne, F.; Samodra, G. Application of a semiquantitative and GISbased statistical model to landslide susceptibility zonation in Kayangan Catchment, Java, Indonesia. Nat Hazards 2017, 87, 437-468.

[25] Saputra, A.; Sartohadi, J.; Hadmoko, D.S.; Gomez, C. Geospatial Assessment of Coseismic Landslides in Baturagung Area. Forum Geografi 2016, 29, 99-114-114.

[26] Priyono, K.D.; Priyono, P. Analisis Morfometri dan Morfostruktur Lereng Kejadian Longsor di Kecamatan Banjarmangu Kabupaten Banjarnegara. Forum Geografi 2008, 22, 72-84-84.

[27] Saputra, A. Pengurangan Risiko Gempabumi Melalui Evaluasi Bangunan Tempat Tinggal dan Lingkungannya di Kecamatan Pleret Kabupaten Bantul, Universitas Gadjah Mada, 2012.

[28] Guillard-Gonçalves, C.; Zêzere, J.L.; Pereira, S.; Garcia, R.A.C. Assessment of physical vulnerability of buildings and analysis of landslide risk at the municipal scale: application to the Loures municipality, Portugal. Nat. Hazards Earth Syst. Sci. 2016, 16, 311-331.

[29] Najib, N.; Karnawati, D.; Sudarno, I. Influence of Geological Condition Towards Slope Stability on Landslide: Case Study in Tengklik Village, Tawangmangu District, Karanganyar Regency, Central Java Province, Indonesia. J. Appl. Geol. 2015, 2.

[30] Verrier, M.F. Identifying areas of potential slope instability in Karanganyar, Indonesia using the analytic hierarchy process (AHP), San Diego State University, 2015.

[31] Setiawan, H.; Hizbaron, D.R. Study of Local People Perception Related to Landslide Hazard: A Case of Tawangmangu SubDistrict Karanganyar Regency Indonesia. Forum Geografi. 2014, 28, 35-42.

Copyright (C) Int. J. of GEOMATE. All rights reserved, including the making of copies unless permission is obtained from the copyright proprietors. 